\title{
Zaręczenie Wzajemne Obojga Narodów - w 220. rocznicę uchwalenia
}

Uchwalone na Sejmie Wielkim przez aklamację 20 października 1791 r. Zaręczenie Wzajemne Obojga Narodów określało stosunek prawny Korony Królestwa Polskiego do Wielkiego Księstwa Litewskiego po wejściu w życie wspólnej dla obu części Rzeczypospolitej konstytucji - Ustawy Rządowej z 3 maja 1791 r. O Zaręczeniu napisano w literaturze historycznej i historycznoprawnej sporo, przypisując jej różną rolę - od regulacji, która znosiła ostatecznie stosunek unii polsko-litewskiej ${ }^{1}$, po akt konstytuujący tę unię

${ }^{1}$ Por. S. Kutrzeba, Unia Polski z Litwa, Lwów 1914, s. 209 oraz idem, Historia ustroju Polski $w$ zarysie, t. II: Litwa, Lwów 1914, s. 200, 215; W. Konopczyński, Dzieje Polski nowożytnej, t. II, Warszawa 1986, s. 238; O. Halecki, Dzieje unii jagiellońskiej, t. II, Kraków 1919, s. 353 (który jednak w późniejszych swych pracach zrewidował swój pogląd, uznając istnienie federacyjnej struktury państwa do końca I Rzeczypospolitej); B. Leśnodorski, Dzieło Sejmu Czteroletniego (1788-1792). Studia historycznoprawne, Wrocław 1951, s. 249. Podobnie uważał J. Łojek, Konstytucja 3 maja, Lublin 1981, s. 34. Ten punkt widzenia został zawarty także w starszych wydaniach podręczników z zakresu historii państwa i prawa polskiego: Z. Kaczmarczyk, B. Leśnodorski, Historia państwa i prawa Polski, t. II, Warszawa 1966, s. 532 oraz J. Bardach, B. Leśnodorski, M. Pietrzak, Historia państwa i prawa polskiego. Warszawa 1976, s. 318. Ostatnio podobny pogląd wyraził W. Uruszczak, Historia państwa i prawa polskiego, t. I (966-1795), Warszawa 2010, s. 205-207, rozszerzając koncepcję jedności Rzeczypospolitej na cały okres po 1569 r. Stanowisko to pozostaje jednak odosobnione. 
w nowym kształcie i nowych warunkach prawno-ustrojowych ${ }^{2}$. Nie pozostawia wątpliwości fakt dużego znaczenia tego dokumentu dla określenia wzajemnych relacji obu narodów, $z$ tego też względu warto przypomnieć go raz jeszcze w rocznicę jego uchwalenia.

Reforma ustrojowa podjęta na Sejmie Czteroletnim musiała odnieść się m.in. do tak ważnej kwestii jak wzajemny stosunek prawny Korony Królestwa Polskiego i Wielkiego Księstwa Litew-

2 Por. W. Smoleński, Sprawa stosunku Litwy do Polski na Sejmie Wielkim, [w:] Księga pamiatkowa ku czci B. Orzechowicza, Lwów 1916, s. 431-444; W. Konopczyński, Przegląd badań nad dziejami Litwy w XVIII wieku, (1686-1795), [w:] Pamiętnik VI Powszechnego Zjazdu Historyków Polskich w Wilnie 17-20 września. 1935 r., t. I: Referaty, Lwów 1935, s. 37 i n.; E. Rostworowski, „Marzenie dobrego obywatela”, czyli królewski projekt konstytucji, [w:] Legendy i fakty XVIII w., Warszawa 1963, s. 407 i n., 439-441, 451-453; J. Malec, Problem stosunku Polski do Litwy w dobie Sejmu Wielkiego (1788-1792), Czasopismo Prawno-Historyczne 1982, t. XXXIV, z. 1, s. 31-50; idem, Próby ściślejszego zespolenia Litwy z Korona $w$ latach 1764-1786, Lituano-Slavica Posnaniensia 1987, Studia Historica II, s. 167-185; idem, Walka szlachty litewskiej o zachowanie III Statutu w drugiej połowie XVIII wieku, Czasopismo Prawno-Historyczne 1992, t. XLIV, z. 1-2, s. 65-72; idem, Sejm grodzieński 1793 roku a unia polsko-litewska, [w:] Parlament, Prawo, Ludzie. Studia ofiarowane Profesorowi Juliuszowi Bardachowi w sześćdziesięciolecie pracy twórczej, Warszawa 1996, s. 148-153; idem, Szkice z dziejów federalizmu i myśli federalistycznej $w$ nowożytnej Europie, Kraków 2003, s. 90-138; J. Michalski, Zagadnienie unii polsko-litewskiej $w$ czasach panowania Stanisława Augusta, Zapiski Historyczne 1986, t. LI, z. 1, s. 97-130; J. Bardach, Konstytucja 3 maja a unia polsko-litewska, Przegląd Historyczny 1991, t. LXXXII, z. 3-4, s. 383-410; idem, Konstytucja 3 maja a Zaręczenie Wzajemne Obojga Narodów 1791 roku, Studia Iuridica XXIV 1992, s. 15-26; idem, O Rzeczpospolitą Obojga Narodów, Dzieje Narodu i Państwa Polskiego 2010, I-10, s. 55-63; Dzieje Polski, red. J. Topolski, Warszawa 1976, s. 387. Także J. Bardach, Krewo i Lublin, s. 583 pisze, że unię zniweczyły dopiero rozbiory. Do wyżej wyrażonego poglądu zdaje się skłaniać także historiografia litewska. Por. M.A. Jućas, Litowskaja szlachta $i$ carizm $w$ XVIII w. Po materialam szlachetskich sejmikov, [w:] Feodalnaja Rossija wo wsemirnoistoriczeskom processe. Sbornik statiej poswiaszcz. J.B. Czerepninu, Moskwa 1972, s. 409. Obecnie przeważa opinia, że 2. połowa XVIII stulecia, a zwłaszcza ustawodawstwo Sejmu Czteroletniego, prowadząc do całkowitej niemalże centralizacji aparatu władzy wykonawczej, nie znosiły bynajmniej stosunku unii między Polską i Litwą, zachowując nadal federacyjny charakter państwa. 
skiego. Starły się wówczas dwie koncepcje określające relację pomiędzy obu członami Rzeczypospolitej Obojga Narodów - unitarna, zakładająca utworzenie jednolitego państwa (reprezentowana m.in. przez Stanisława Augusta czy H. Kołłątaja) oraz federalistyczna, postulująca utrzymanie odrębności państwowej Litwy ${ }^{3}$.

W toku prac nad szeroko zakrojonym planem reformy ustroju państwowego istotne znaczenie odgrywała, niesłychanie wówczas aktywna, publicystyka polityczna. Wielu autorów podnosiło w swych pracach także wątek określenia wzajemnego stosunku dwu członów składających się na Rzeczpospolitą: Korony i Litwy.

Do najważniejszych dla przyszłej reformy państwa należą prace Hugona Kołłątaja, a wśród nich Listy Anonima oraz Prawo polityczne narodu polskiego. Kołłątaj był bowiem nie tylko ideologiem nowego porządku, lecz także autorem pełnego projektu konstytucji, z którego wiele zaczerpnięto, opracowując Konstytucję 3 maja.

W Listach Anonima, pochodzących z przełomu października i listopada 1788 r., Kołłątaj główne odrębności między prowincjami Rzeczypospolitej widział jedynie w zakresie prawa sądowego i nielicznych prerogatyw. Postulował w związku z tym opracowanie jednolitego dla całego państwa kodeksu oraz bezwzględne wprowadzenie wspólnego języka ojczystego - polskiego, co miało w rezultacie jego zdaniem znieść wszelkie istniejące jeszcze różnice ${ }^{4}$. Proponował także, aby w celu pełnego ujednolicenia administracji Departament Skarbowy kończącej swój żywot Rady Nieustającej skupił zarząd obu skarbów na wzór Departamentu Wojskowego, który „zatrudnia się dozorem wojska obydwu narodów”, czy Komisji Edukacyjnej, która „rządzi edukacją w Koronie i Litwie”5. Wypowiadał się za zniesieniem alternaty sejmowania i uznaniem Warszawy za stolicę całego państwa (także Litwy). Stanowisko to

3 J. Bardach, Konstytucja 3 maja a unia polsko-litewska, s. 383.

4 Por. H. Kołłątaj, Listy Anonima i Prawo polityczne narodu polskiego, t. I, Warszawa 1954, s. 367-370 (cz. 2, list 7).

5 Ibidem, s. 220. Podkreślić wypada, że uznając równe prawa Korony i Litwy, Kołłątaj proponował, by połowa radców (konsyliarzy) mających wchodzić w skład Departamentu Skarbu pochodziła z Litwy, a połowa z Korony. Por. też J. Bardach, Konstytucja 3 maja a unia polsko-litewska, s. 385 oraz J. Michalski, op.cit., s. 113. 
Kołłątaj potwierdził bardzo wyraźnie - na co zwrócił już uwagę J. Bardach - w zachowanym w rękopisie piśmie $O$ sejmie: „Jeżeli chcemy być trwale wolnemi, pamiętajmy, że nam się łączyć nie rozdzielać potrzeba, powinniśmy mieć jedną wolności naszej stolicę: jedno wojsko, skarb i inne magistratury powinny być wspólne dla obydwu narodów"6.

Kołłątaj nie dostrzegał natomiast, lub raczej nie chciał dostrzec, pozostałych odrębności ustrojowych między Koroną a Litwą, ograniczając się do stwierdzenia - w innym miejscu - zupełnej jednolitości, wynikającej z powołania wspólnego rządu na szczeblu centralnym (tzn. Rady Nieustającej), w czym widział jednostajność całego systemu prawa politycznego Rzeczypospolitej. Można sądzić, iż było to działanie przezeń zamierzone. Zaznaczając jedynie bezsporne różnice w zakresie prawa sądowego, a pomijając inne, czynił to celowo, pragnąc, aby w przyszłości tym łatwiej można było realizować dalszą centralizację aparatu państwowego oraz administracji lokalnej w państwie.

W Prawie politycznym, wydanym w 1790 r., a pomyślanym jako gotowy projekt przeznaczony dla powołanej na sejmie w celu reformy ustroju Deputacji dla Poprawy Formy Rządu, Kołłątaj rozwinął zawarte w Listach Anonima postulaty, tym razem jednak skłaniał się już ku utrzymaniu w pełni postanowień unii lubelskiej, których odmiana „inaczej nastąpić nie może, tylko za jednostajnym zezwoleniem wszystkich posłów na mocy instrukcji danej od województw" . J. Bardach widzi w tym próbę przekonania szlachty litewskiej, przed wyborami drugiego kompletu posłów na Sejm Czteroletni, że reforma mająca przeobrazić Rzeczpospolitą w scentralizowane państwo unitarne nie zostanie im narzucona lecz powinna nastąpić za jednomyślną zgodą posłów, poprzedzoną uchwałami sejmików zawartymi w instrukcjach poselskich ${ }^{8}$.

Kołłątaj nie był w swych poglądach odosobniony. Zbliżony do powyższego punkt widzenia zaprezentował w tym samym czasie

${ }^{6}$ H. Kołłątaj, O sejmie, Bibl. Ossol., rkps 1778/III, s. 41. Cyt. za: J. Bardach, Konstytucja 3 maja a unia polsko-litewska, s. 386.

7 H. Kołłątaj, Listy Anonima, t. II, s. 244.

8 J. Bardach, Konstytucja 3 maja a unia polsko-litewska, s. 386. 
inny działacz Kuźnicy Kołłątajowskiej - ks. Franciszek Salezy Jezierski, autor Wzmianki krótkiej o zjednoczeniu Księstwa Litewskiego z Królestwem Polskim $w$ duchu wolności i równości ${ }^{9}$. Takie bądź podobne opinie podzielała zresztą większość członków stronnictwa patriotycznego, czego wyrazem mogą być późniejsze uchwały Sejmu Czteroletniego.

Podkreślić wypada, że w poglądach większości publicystów okresu Sejmu Wielkiego zaznacza się wyraźna dążność do scentralizowania i ujednolicenia władzy wykonawczej. Sam problem unii schodzi tu na plan drugi; niejednokrotnie służy on do uzasadnienia potrzeby owej centralizacji, którą autorzy określają jako rozwinięcie i realizację zasad zawartych $\mathrm{w}$ unii lubelskiej. Żaden $\mathrm{z}$ autorów nie mówił jednoznacznie o zniesieniu stosunku unijnego. Wydaje się to $\mathrm{w}$ pełni zrozumiałe, unia Polski $\mathrm{z}$ Litwą była bowiem rozwiązaniem ustrojowym, którym Polacy jakże często szczycili się wobec innych narodów; była nie bez racji przedmiotem dumy. $Z$ drugiej strony niektóre zawarte w niej zasady, w pełni akceptowane i zrozumiałe w wieku XVI czy XVII, poczęły tracić swe znaczenie, a nawet przeszkadzać w 2. połowie XVIII w., dlatego też należało je zaktualizować zgodnie $z$ wymogami potrzeb politycznych epoki. Toteż o ile rezygnacja $z$ samej unii nie byłaby możliwa, chociażby $z$ uwagi na zdecydowany opór szlachty litewskiej, o tyle dalsze jej zacieśnienie (jak to wówczas określano) było pożądane i w pełni akceptowane przez światłych obywateli obojga narodów.

Uchwalona 3 maja 1791 r. Ustawa Rządowa pomijała milczeniem problem unii polsko-litewskiej. Nie ma w niej stosowanego wcześniej powszechnie określenia „Rzeczpospolita Obojga Narodów” czy „Rzeczpospolita” w rozumieniu związku dwóch państw. Państwo określa się jako „Ojczyzna” lub „Polska”, a stany skonfederowane wymienia preambuła Konstytucji jako „reprezentantów narodu polskiego". Jedyna wzmianka o Wielkim Księstwie Litewskim występuje w tytule monarchy i podpisie marszałka konfederacji litewskiej ${ }^{10}$. Zwykło się uważać, że $z$ milczenia konstytucji o unii wypływa wniosek, iż znosiła ona tym samym federacyjny charakter pań-

9 Druk współczesny, b.m. i r. (1790).

10 J. Bardach, Konstytucja 3 maja a unia polsko-litewska, s. 389. 
stwa $^{11}$. Brak ku temu podstaw - choć „zapewne taka była cicha intencja Stanisława Augusta" ${ }^{12}$ - biorąc zwłaszcza pod uwagę późniejsze ustawodawstwo Sejmu Czteroletniego, gdzie wyraźnie mówi się nadal o unii łączącej oba kraje, a nawet o jej odnowieniu ${ }^{13}$. Nie budzi natomiast wątpliwości fakt, że Konstytucja 3 maja zespalała władzę w państwie na jej szczeblu centralnym, osłabiając w ten sposób faktyczną treść samej unii, która od tego czasu funkcjonowała bardziej jako przejaw tradycji ustrojowej niż jako rzeczywisty związek dwu samoistnych organizmów państwowych powiązanych ze sobą osobą monarchy i wspólnym organem ustawodawczym. W tym ostatnim zresztą rozumieniu unia realna straciła swój dawny charakter już z chwilą powołania Rady Nieustającej.

Ustawa Rządowa wprowadzała wspólny, najwyższy organ władzy wykonawczej - Straż Praw oraz wspólne komisje rządowe, z których tylko dwie: Wojska i Edukacji Narodowej były w tym czasie połączone. Dwie następne: Policji i Skarbu złączyły się dopiero w kilka miesięcy później (pierwsza w czerwcu, druga w październiku), nie bez znacznych zresztą oporów ze strony posłów prowincji litewskiej. Konstytucja pozostawiała nadal odrębne, choć identyczne co do nazwy i kompetencji, urzędy centralne i lokalne, odrębne sądownictwo, sesje prowincjonalne sejmu, zachowywała też przyznaną Litwie w 1673 r. alternatę sejmu ${ }^{14}$, a także alternatę miejsca obrad komisji wielkich.

11 Por. S. Kutrzeba, Unia Polski z Litwa, s. 209; B. Leśnodorski, Dzieło Sejmu, s. 239-241; idem, Institutions polonaises au siecle des Lumiéres, Warszawa 1962, s. 31-32.

12 J. Michalski, op.cit., s. 114.

13 Por. Volumina Legum (dalej: VL), t. IX, Kraków 1889, s. 316. Już w dwa dni po uchwaleniu Konstytucji, w Deklaracji Stanów Zgromadzonych z 5 maja nastąpił powrót do terminologii unijnej. Mowa jest tam bowiem o „państwach Korony Polskiej i Wielkiego Księstwa Litewskiego” oraz o instygatorach „Obojga Narodów”. J. Bardach słusznie dopatruje się w tym „chęci upewnienia Litwinów, że dualistyczna organizacja państwowa nie uległa zmianie" (Konstytucja 3 maja a unia polsko-litewska, s. 398). Por. też Konstytucja 3 maja 1791 r., oprac. J. Kowecki, Warszawa 1981, s. 105.

14 Sprawą alternaty (zmiany miejsca obrad) sejmu zajmowano się wówczas znacznie mniej niż uprzednio, tym bardziej znamienne jest jej utrzymanie. Nawet w instrukcjach sejmikowych z Litwy żądanie jej przestrzega- 
Dla Litwinów istotniejsze od zaznaczenia odrębności narodu było zabezpieczenie odrębności prerogatyw prowincji litewskiej i zapewnienie jej równorzędnej $\mathrm{z}$ Koroną pozycji prawnoustrojowej w ramach Rzeczypospolitej ${ }^{15}$. Mówiąc o sobie jako o odrębnym narodzie litewskim, rozumieli to zapewne bardziej w sferze tradycji niż rzeczywistego poczucia odrębności narodowej. Parafrazując określenie używane niegdyś przez Rusinów, można zatem przyjąć w odniesieniu do szlachty litewskiej, że była ona gente Lithuani natione Poloni. J. Bardach dodaje, że „posłowie i senatorowie litewscy zgodzili się na Konstytucję Majową, by umożliwić dokonanie reformy politycznej Rzeczypospolitej i umocnić ją w obliczu zewnętrznych zagrożeń, $z$ których zdawano sobie dobrze sprawę. Nie zamierzali oni jednak rezygnować z podmiotowości politycznej i prawnej Wielkiego Księstwa. Wykorzystując fakt, że Konstytucja 3 maja uchyliła się od określenia wzajemnego stosunku Korony i Litwy, reprezentacja litewska podjęła obronę podmiotowości politycznej Wielkiego Księstwa poprzez odpowiednią redakcję związanych $\mathrm{z}$ nową Konstytucją ustaw szczegółowych normujących zreformowany ustrój Rzeczypospolitej. Była to akcja celowa i konsekwentnie realizowana" ${ }^{16}$.

nia formułowane było nieco słabiej. Świadczy o tym instrukcja sejmiku trockiego: „Przywiązywać sejmujące obrady do jednego miasta, równie jak przywiązywać króla do jednego mieszkania, nie tylko dla Rzeczypospolitej krajowej ustawą niepożyteczną widziemy, ale widziemy szkodliwą i niebezpieczną”. Bibl. Jagiell., rkps 956: „Objaśnienie artykułom instrukcji w r. 1790 na sejmiku w miesiącu novembrze dnia 18 za prawem i uniwersałami ekspediowanym".

15 Świadczą o tym instrukcje sejmików litewskich, które obszernie przytacza J. Bardach, Konstytucja 3 maja a unia polsko-litewska, s. 395 i n. Pisze on m.in., że „instrukcje sejmikowe [...] zmierzały, najogólniej rzecz ujmując, do utrzymania politycznej podmiotowości Wielkiego Księstwa i cechujących go odrębności w funkcjonowaniu Sejmu, strukturze władz i sądownictwa. Podstawami tego partykularyzmu - bo nie separatyzmu były akt Unii lubelskiej i III Statut litewski. Formułując te postulaty sejmik wileński stwierdzał [...], że ma się nimi rządzić „Naród Polski”, poświadczając istnienie w tym czasie - wśród szlachty przynajmniej - dwuszczeblowego pojęcia Narodu Polskiego jako całości obejmującej Koroniarzy i Litwinów” (op.cit., s. 397).

16 Ibidem, s. 395. 
Po uchwaleniu Konstytucji 3 maja przystąpiono do tworzenia zapowiedzianych w Ustawie Rządowej komisji wielkich. Ponieważ Komisja Wojskowa Obojga Narodów została powołana do życia jeszcze w listopadzie 1788 r., Komisja Edukacji Narodowej zaś istniała nieprzerwanie od 1773 r., należało zająć się sprawą utworzenia dwu pozostałych komisji - Policji i Skarbu.

Podkreślić wypada, że powołanie wspólnej Komisji Policji nie budziło już tak zasadniczych sprzeciwów strony litewskiej jak w przypadku Komisji Wojska. Wydaje się, iż było to spowodowane nie tylko oddziaływaniem na posłów Konstytucji 3 maja, lecz również tym, że Komisja owa nie miała takiego znaczenia jak odpowiednie magistratury wojska czy skarbu, oraz faktem, że nigdy wcześniej nie istniały dwie odrębne komisje policji, istniał natomiast od 1776 r. wspólny departament policji w Radzie Nieustającej.

Po przerwie wakacyjnej, w październiku 1791 r., sejm przystąpił do organizowania Komisji Skarbowej. Potrzebę wspólnej magistratury skarbu dostrzegano tym razem także na prowincji. Świadczą o tym instrukcje sejmiku wołyńskiego w Łucku z listopada $1790 \mathrm{r}$. oraz sejmiku powiatu pińskiego $\mathrm{z}$ tegoż roku ${ }^{17}$. Poparły tę koncepcję także dwa sejmiki litewskie: kowieński i orszański ${ }^{18}$.

Za złączeniem skarbów opowiedziała się zgodnie większość posłów koronnych. Wypowiadali się w tym duchu posłowie: wołyń-

17 „Chcąc zaś w krajach Rzeczypospolitej jedność interesów i związki w prowincjach osób i równość interesów wszystkich prowincji wspólnym obywatelom w razie wiadomości i do utrzymania wspólnych potrzeb równą gorliwość - obligujemy jaśnie oświeconych i jaśnie wielmożnych posłów, by starali się ile to być może, aby komisje skarbowe obojga narodów w ciało jednej komisji złączone były". K. Pułaski, Szkice i poszukiwania historyczne, III: Uchwały sejmiku wołyńskiego $w$ Łucku w 1790 roku, Petersburg 1898, s. 183-184. W instrukcji domagano się także przyznania równej liczby mandatów poselskich każdej z trzech prowincji: „Jako kraje Rzeczypospolitej na trzy dzielą się prowincje, tej wymagają równości i sprawiedliwości by równą reprezentacją do praw Rzeczypospolitej stanowienia przykładali się, tak aby mniej posłów mające, jako jest Małopolska, praw większości wotów innych prowincji sobie narzuconych znosić nie były obowiązane" (s. 181). Por. też R. Horoszkiewicz, Instrukcje sejmiku pińskiego z czasów Sejmu Czteroletniego, Ziemia 1927, r. XII, nr 21, s. 435-437.

18 J. Bardach, Konstytucja 3 maja a unia polsko-litewska, s. 400. 
scy - August Świętosławski19, Ignacy Krzucki²0 i Józef Piniński²1; poznański - Antoni Gliszczyński ${ }^{22}$; żmudzki - Maurycy Karp ${ }^{23}$ oraz inowrocławski - Józef Trzebuchowski ${ }^{24}$. Sprzeciwił się temu natomiast marszałek konfederacji litewskiej, dowodząc, że „komisja wojskowa nie powinna w tym wypadku służyć za przykład, stworzyła ją bowiem konieczność utrzymania w armii jedności i ładu.

19 AGAD, ASW 22, sesja 121, k. 234.

20 „Nasłuchałem się od pierwszego składu posłów prowincji litewskiej o potrzebie połączenia skarbu, takoweż wnioski i nowoprzybyli czynili koledzy. [...] niepotrzeba usposabiać rozdziałami magistratur do odpadnienia z czasem Litwy". Ibidem, k. 236.

21 „Próżno się prowincja litewska zastawia unią, bo ta o rozdziale skarbów żadnej wzmianki nie czyni, a gdy już inne rządowe magistratury połączone zostasły, za cóż tylko w oddziale skarbów ma zostawiać jeszcze pamiątka przedkilkowiecznej niejedności”. Ibidem, sesja 122, k. 249 oraz Głos jaśnie wielmożnego Józefa Pinińskiego wojskiego wyższego włodzimierskiego, posła województwa wołyńskiego, na sesji sejmowej dnia 14 października $w$ materii połaczenia skarbów litewskiego z koronnym (b.m. i r.).

22 AGAD, ASW 22, k. 234.

23 Poddając krytyce pracę Komisji Skarbowej Litewskiej dowodził, że połączony skarb poddany będzie kontroli całego państwa, nie jednej tylko prowincji. Uważał, że niewielkie dochody jakimi dysponuje nie potrzebują rozdzielenia zarządu. „Do administracji skarbu francuskiego - twierdził tysiące milionów, bez przesady mówiąc, w dochodach, wydatkach i długach liczącego, dosyć sześciu osób na tyle ludnych i rozległych prowincji: dosyć jednego ministra. Toż samo mówić o dochodach angielskich i innych przemożnych mocarstw, gdzie bezmierne miliony szczupłej zawiadowców są powierzone liczbie i są dobrze rządzone. A u nas na kilakdziesiąt milionów naszych, co ledwo kilkanaście uczyni holenderskich, a dziesiątek niemieckich,, trzeba czterech ministrów, 21 kommissarzów, rachmistrzów, kasjerów, kontrollerów i Bóg wie jakiego nazwiska i zdatności officjantów! Radził natomiast pozostawić osobne sądownictwo skarbowe: [...] sądowość przeto od administracji skarbu ma być oddzielona, a najbliżej do najodleglejszych prowincji przymknięta”, Głos Maurycego Franciszka Karpia posła z Księstwa Żmudzkiego. W Warszawie $w$ drukarni uprzywilejowanej pana Zawadzkiego (b.r.).

24 „Wszakże jedno składamy ciało Rzeczypospolitej Polskiej - złączyliśmy rząd, wojsko, policję, edukację - jeden skarb ma być tylko rozłączonym?" Głos jaśnie wielmożnego Trzebuchowskiego stolnika radziejowskiego posła inowrocławskiego na sesji sejmowej d. 14.8.bris 1791 miany za złaczeniem skarbów (b.m. i r.). 
Ze złączenia Komisji skarbowych zamiast pożytku wyniknie szkoda przez narażenie obywateli na długą do Warszawy podróż, a głównie - dla zwątlenia świętości unii”25.

Poparła marszałka znaczna część posłów litewskich, co spowodowało niespodziewaną zmianę kierunku dalszej dyskusji. Nie chcąc całkowicie zrazić do siebie Litwinów, posłowie koronni zaczęli wycofywać się z żądania wspólnej magistratury skarbu. W tym duchu wypowiedzieli się poseł krakowski Stanisław Sołtyk ${ }^{26}$ i poseł lubelski Adam Czartoryski ${ }^{27}$, a także ci spośród Litwinów, którzy początkowo byli za złączeniem komisji skarbowych - Ludwik Gutakowski poseł orszański ${ }^{28}$ oraz Julian Ursyn Niemcewicz poseł inflancki ${ }^{29}$.

Śledząc dalszą dyskusję, można odnieść wrażenie, że wśród Litwinów poczęła narastać obawa o utratę odrębności swej prowincji, a w rezultacie zniesienie samej unii ${ }^{30}$. Swwiadczą o tym wypo-

25 W. Smoleński, Ostatni rok, s. 126. Dodawał przy tym: „Przywileje narodów nie są własnością jego reprezentantów, ani nawet całego żyjącego pokolenia. My nie mamy prawa ich się wyrzekać, a otrzymawszy od przodków powinniśmy je przekazać w całości potomkom”. N. Kostomarow, Poslednije gody Rieczipospolitej, t. I, Petersburg 1886, s. 536 (cyt. za: J. Bardach, op.cit., s. 400 w przekładzie tegoż).

26 AGAD, ASW 22, k. 265-266.

27 „Rozumiem, że złączenie to byłoby rzeczą użyteczną. Lecz moim równie zdaniem, tyle rzecz jest użyteczna ile nie ciągnie za sobą rozjątrzenia”. Ibidem, k. 246.

28 „[...] przekonałem się o potrzebie złączenia i wyznam nawet, że mnie najmniej konwinkują przywileje unii, bo i owszem tam znajduję wyrazy dążące do najsilniejszego dwóch narodów w jedno ciało Rzeczypospolitej połączenie. Ale znajdując się na sesji prowincjonalnej widząc jednomyślność za oddzielnością choć mam przeciwną instrukcją chętnie woli prowincji ustępuję, bo nigdy nie jestem tego zdania, aby jedna instrukcja tamować mogła wolę powszechności”. Ibidem, k. 245-246.

29 „I przekonanie i instrukcja moja były za złączeniem skarbów, ale jak pierwsze, tak druga ustąpiły względowi na jedność umysłów na czym potęga państw się zasadza”. Ibidem, k. 255.

30 Podobnie ocenia to J. Bardach, Konstytucja 3 maja a unia polsko-litewska, s. 392 i n., dostrzegając takie obawy Litwinów już w toku uchwalania samej Konstytucji i tym tłumacząc kompromisowe stanowisko posłów prowincji litewskiej wobec ustawy zasadniczej. 
wiedzi posłów: nurskiego Aleksandra Zielińskiego ${ }^{31}$, bracławskiego Bogusława Mirskiego ${ }^{32}$ oraz kasztelana witebskiego Adama Rzewuskiego $^{33}$. Głos zabrał także król, który widząc niebezpieczeństwo zrażenia sobie całej niemal Litwy, a nawet groźbę otwartego konfliktu z reprezentacją Wielkiego Księstwa, zdecydował się ustąpić żądaniom tej prowincji ${ }^{34}$.

Ostatecznie na sesję 17 października deputacja konstytucyjna przygotowała projekt mówiący o powołaniu dwu odrębnych komisji skarbowych. Gdy miano przystąpić do głosowania nad projektem „stawający za złączeniem skarbów sprzeciwili się z żywością tej oppozycji. Utrzymywanie jej z drugiej strony, mianowicie od posłów litewskich $\mathrm{z}$ równą żywością, sprawiło $\mathrm{w}$ izbie niejakie poruszenie i wrzawę" ${ }^{35}$. Józef Piniński z Wołynia przypomniał Litwinom, że projekt wspólnej komisji wyszedł wszak od nich samych. „Powiedziano, że Litwa jest oddzielnym księstwem od Polski, nigdy od unii nie słyszała tego ta świątynia i bodajby była nie słyszała nigdy [...].

31 „Dobro tego powszechne wyciąga, aby każdy obywatel, a tym bardziej cała prowincja została nienaruszoną w przywilejach swoich. [...] gdy prowincja jednozgodnie utrzymuje oddzielność skarbu, zostawić jej zupełną wolność pownniśmy". Ibidem, k. 264.

32 Głos jaśnie wielmożnego Bogusława Mirskiego podkomorzego i posła brasławskiego miany na sesji sejmowej dnia 14.8.bris 1791 roku (b.m. i r.).

33 AGAD, ASW 22, k. 260-261.

34 „To też jest i dla mnie powodem, abym najusilniej upraszał wszystkich tu wystawujących potrzebę skarbów złączenia, aby dziś przychylili się po bratersku do żądań prowincji litewskiej, i dalszemu czasowi zostawili, jeżeli kiedy mocniejszą nie upatrzemy potrzebę rozwiązania tej kwestii”. Ibidem, k. 247. Spowodowane to było dążeniem obozu reformatorskiego do zgody narodowej, co miało w rezultacie pozbawić argumentów do interwencji dwór petersburski. Potwierdza to list Stanisława Augusta do posła polskiego w Petersburgu, Augustyna Debolego, z 15 X 1791 r. Król pisał: „Ja widząc zaciętą rezolucyją całej Litwy, nawet i podkanclerzego litewskiego pretendowania oddzielnej Komisyi Skarbowej Litewskiej tak dalece, że oczywiście obawiać się należało odszczepienia i schizmy politycznej, sądziłem być nieodbitą potrzebą utemperowania natarczywej chęci koronnych prowincyj o zjednoczenie tych Komisyj, przedkadając, że utrzymanie jedności przeważać powinno nad wszystkie inne względy". Zbiór Popielów 413, cyt. za: J. Michalski, op.cit., s. 118 i n.

35 Ibidem, sesja 123, k. 274. 
Nie mam celu odebrania egzystencji imienia narodu litewskiemu chcę tylko odebrać egzystencję różnicy, wolałbym raczej żeby w magistraturach wszyscy Litwini siedzieli, aniżeli szlad ten niejedności zostawiać. [...] Mówiąc za złączeniem skarbów, mówię za świętością unii"36. Szczerość tej wypowiedzi zdaje się mocno wątpliwa, więcej w niej było chęci zamącenia dalszej dyskusji, o co nieustannie starali się posłowie $z$ Wołynia.

Replikował zaraz marszałek konfederacji litewskiej, dowodząc: „Nie nazwałem oddzielnym księstwem Wielkiego Księstwa Litewskiego, alem go nazwał księstwem udzielnym, chcę go widzieć najściślej połączonym z prowincjami koronnemi”, dodając jako argument wynikający z zapisu unii - a przemawiający za odrębnością komisji - fakt, że wyróżniła ona dwóch podskarbich (koronnego i litewskiego). Chcąc grać na zwłokę, zaproponował odłożenie sprawy złączenia komisji do przyszłego sejmu ${ }^{37}$.

Inny z Litwinów, kasztelan trocki Kazimierz Plater, podkreślając, że Wielkie Księstwo na sesji prowincjonalnej jednomyślnie zawarowało sobie oddzielne komisje, ubolewał nad narzucaniem Litwie warunków godzących w jej prawa. Powoływał się na artykuł 9 aktu unii lubelskiej nakazujący zachować wszystkie prerogatywy i urzędy litewskie, dowodząc, że „złamanym będzie traktat unii, kiedy kommissjów, to jest wysadów skarbowych oddzielnych dla obu narodów - kiedy urzędów i dostojeństw w podskarbich swoich, kiedy sądów właściwych, kiedy prawa swojego mieć nie będzie Litwa, która wszak nie może być uważaną za prowincję względnie jednego ciała, lecz za naród względnie narodu drugiego, w takiej mocy czynić mogący dziasiaj dla trwałości węzła, w jakiej był, kiedy tą świętą unią złączył się z Koroną"38.

36 Ibidem, k. 275. Poparł go inny poseł z Wołynia Stanisław Hulewicz (k. 276-277).

37 Ibidem, k. 275-276.

38 Głos jaśnie wielmożnego Kazimierza Konstatntego hrabiego Platera kasztelana trockiego na sesji sejmowej 17 października $1791 \mathrm{w}$ materii rozdzielności skarbów miany (b.m. i r.). Po uchwaleniu Zaręczenia wzajemnego obojga narodów Plater zmienił zdanie i w pełni poparł złączenie komisji na nowych warunkach (Por. Głos tegoż na sesji sejmowej 21 octobra 1791 (druk wydany łącznie $z$ poprzednim). 
Poseł bracławski Tomasz Wawrzecki apelował do posłów wołyńskich, by przez wzgląd na dobro prowincji litewskiej odstąpili swych żądań $^{39}$. Poparł go poseł ziemi nurskiej, argumentując, że odrębność komisji zabezpiecza w razie napaści i zajęcia przez nieprzyjaciela jednego ze skarbów zachowanie drugiego. Sprzeciwił się także narzucaniu Litwie niechcianych rozwiązań, podkreślając, że gdy wolność „w dniu 3 maja dla każdego zabezpieczoną została, jakże odejmować ją możemy udzielnemu Księstwu Litewskiemu. Udzielnym słusznie go nazywać mogę, bo czytając kronikę i dzieje narodu naszego, nie znajduję narodu litewskiego od narodu polskiego zawojowanym, ale dobrowolnie połączonym, jako przyjaciel z przyjacielem" ${ }^{40}$.

Wreszcie pod koniec sesji kompromisowe rozwiązanie zaproponował członek deputacji konstytucyjnej Stanisław Potocki, „aby zawarować Księstwu Litewskiemu równą liczbę ministrów i kommissarzów skarbowych, jaka w Koronie, a skarby połączyć" 41 .

Na żądanie króla propozycja ta odesłana została do rozważenia na sesję prowincjonalną litewską. Posłowie litewscy dwukrotnie zbierali się w tym celu ${ }^{42}$. Ostatecznie marszałek konfederacji litewskiej Kazimierz Nestor Sapieha przyniósł na sesję 20 października projekt swej prowincji zatytułowany Zaręczenie wzajemne obojga narodów, zredagowany - wedle ustaleń Adolfasa Šapoki - przez posłów Ksawerego Chomińskiego i Józefa Niesiołowskiego ${ }^{43}$. Przedkładając ów projekt, Sapieha oświadczył, że Litwa „godzi się na jeden skarb, na jedną onego administracją; warunki tylko udzielność jej dowodzące pragnie mieć zachowane. Aby mimo zatrzymania równej liczby ministrów i urzędników nadwornych dla prowincji litewskiej, $z$ temiż samemi tytułami i obowiązkami, jakie Korona kiedykolwiek mieć będzie, równa i taka połowa osób z Litwy jaka będzie $z$ prowincjów koronnych determinowana składała kommissją skarbową i wojskową i prezydencja w nich równym wymiarem

39 AGAD, ASW 22, k. 277.

40 Ibidem, k. 279.

41 Ibidem, k. 282.

42 Por. W. Smoleński, Sprawa stosunku Litwy, s. 442.

43 Zob. J. Bardach, Konstytucja 3 maja a unia polsko-litewska, s. 401. 
czasu, raz przy Litwie drugi raz przy Koronie zostawała”; podsumowując ów akt, Sapieha zaznaczał: „Panowaniu Zygmunta Augusta winny narody unią. Panowaniu Stanisława Augusta winne będą tym silniejsze spojenie $z$ oznaką udzielności swojej”44.

Uchwałę przyjęto w tym samym dniu przez aklamację. Poparł ją także król. „Dążę - mówił Stanisław August - aby naród był wzmocniony, żądam, aby projekt od prowincji litewskiej podany był jednomyślnie przyjęty. [...] jedność nade wszystko od nas powinna być żądana, a ta jedność $\mathrm{w}$ domu pomyślności nasze zagruntuje, a zewnątrz odstraszenie sprawi. [...] Czy to nie najmilszy stawia się widok przed nami, który przed dwiema wiekami unią zawartą między dwiema narody, tę mówię świętą unią usolidni i uwieczni, czyż to łechtać nie powinno miłości własnej Polaka, gdy dziś jednym słowem zgody zrobi to, co cały naród polski i litewski stopi w masę taką, która przez ścisłość zrobi się tym bardziej poważniejszą, silniejszą i nie zostawi miejsca do sideł i zamiarów podkopanych"45.

Uchwalenie Zaręczenia dawało satysfakcję posłom litewskim, było także po myśli króla, który realizował tym samym, co prawda częściowo, swoje wcześniejsze plany zmierzające do scentralizowania i ujednolicenia administracji w państwie ${ }^{46}$. Po przyjęciu nowego prawa „złożyli ichmość marszałkowie konfederacji obojga narodów podziękowanie Najjaśniejszemu Panu za okazane dowody miłości

44 AGAD, ASW, 22, k. 292-293. Nawiązał do jego wypowiedzi, dzień po uchwaleniu Zaręczenia, marszałek sejmu Stanisław Małachowski, mówiąc: „Oddzielne lubo prowincji nazwiska w dwuchsetnym lat biegu z okładem utrzymujące się nierozdzielne zawsze sprawiało obywatelstwo, bo tak szczycił się Polak być $z$ tej prowincji jak i z drugiej; odnawia się tylko słodka pamięć spojenia tych dwóch narodów, która i następności miłą będzie, gdy spojrzy, że za Zygmunta Augusta zrządzone, a za Stanisława Augusta w pełnej braterskiej harmonii wspanialszym pamięci przywiedzeniem jest uczczone”. Ibidem, s. 315.

45 AGAD, ASW 22, k. 303-304.

46 Por. projekt królewski Ucalenie unii Wielkiego Księstwa Litewskiego z Koroną Polska (J. Malec, Szkice z dziejów federalizmu, s. 65 i n.). Jak twierdzi E. Rostworowski, „kompromisowa uchwała [...] daleka jednak była od pierwotnego zamiaru Stanisława Augusta, aby znieść wszelkie dwoistości czy alternatywy stanowisk, urzędów i dygnitarstw” (Ostatni król Rzeczypospolitej, Warszawa 1966, s. 248). 
narodów, którym króluje, i które tym ściślej z sobą złączone pragnął w dniu dzisiejszym oglądać, upraszając Jego Królewską Mość o pozwolenie ucałowania ręki Jego, która przez całą izbę, Senat, ministerium i stan rycerski porządkiem województw przywoływany uskutecznione zostało" 4 .

Zaręczenie wzajemne obojga narodów wprowadzało równouprawnienie prowincji litewskiej w organach centralnych Rzeczypospolitej oraz utrzymywało pewne odrębności instytucjonalne ${ }^{48}$. Było ono zwartym, niezbyt obszernym tekstem. Poza uzasadniającą jego uchwalenie preambułą podkreślającą dualistyczny charakter państwa oraz zakończeniem, dzieliło się na pięć punktów zawierających gwarancje dla prowincji litewskiej.

Powołując się na istniejący między Koroną i Litwą związek unii, a także na jednolitą dla całego państwa ustawę rządową - Konstytucję 3 maja, Zaręczenie ustanawiało wspólny zarząd nad wojskiem i skarbem. Postanowienie to obwarowano jednak pewnymi istotnymi warunkami.

Po pierwsze zagwarantowano Wielkiemu Księstwu Litewskiemu równą z Koroną liczbę przedstawicieli we wspólnych Komisjach Wojska i Skarbu. Komisję Policji pozostawiono w niezmienionym składzie (jedna trzecia komisarzy z Litwy, dwie trzecie $z$ Korony), „Jako skutek dobrowolnego zezwolenia Wielkiego Księstwa Litewskiego", które to ustępstwo nie mogło nigdy w przyszłości stanowić precedensu przy powoływaniu kolejnych wspólnych instytucji. We wszystkich nowo powołanych magistraturach należało także zapewnić Litwie równy ilościowo udział przedstawicieli.

Po wtóre zobowiązywano się utrzymywać w Wielkim Księstwie Litewskim taką samą liczbę ministrów i urzędników narodowych ${ }^{49}$, jaka byłaby w Koronie, $z$ tymi samymi tytułami i uprawnieniami.

Po trzecie w komisji wojska i skarbu przewodnictwo obrad miało przemiennie należeć odtąd do obu prowincji w tym samym wymiarze czasu.

47 AGAD, ASW 22, k. 311.

48 J. Bardach, Konstytucja 3 maja a unia, s. 22 i n.

49 Być może powinno być „nadwornych”, tak przynajmniej w mowie Sapiehy, AGAD, ASW 22, k. 292 oraz u W. Smoleńskiego, Sprawa stosunku Litwy, s. 443. 
Po czwarte kasa skarbowa dochodów publicznych litewskich pozostawać miała na Litwie.

Wreszcie po piąte sprawy sądowe Komisji Skarbowej dotyczące obywateli i spraw litewskich rozpatrywać miał nadal odrębny dla Wielkiego Księstwa sąd skarbowy, złożony z osób niewchodzących w skład komisji i działający podług osobnego dla Litwy prawa.

Wszystkie wymienione zasady uznano „artykułami aktu unii” Korony i Wielkiego Księstwa Litewskiego, mającymi taką samą moc jak wcześniejsze postanowienia unii lubelskiej. Zaręczenie stanowić miało artykuł pactorum conventorum obowiązujący zarówno aktualnego monarchę, jak i jego następców ${ }^{50}$. Weszło ono ostatecznie do Konstytucji 3 maja jako jej część składowa.

Kołłątaj, oceniając dwa lata później rolę i znaczenie tego aktu, pisał: „Szlachetna, a raczej braterska ofiara prowincji koronnych ułatwiła wszystko. Ponowione zostały między Litwą i Koroną święte unii śluby; zapadła pamiętna ustawa, na mocy której do wszystkich magistratur rządowych połowa obywateli litewskich, a połowa koronnych obierana być miała; choć Litwa trzeciej części, ani w ludności, ani w bogactwach, względem Korony nie wynosi" ${ }^{51}$. Trudno nie zgodzić się z księdzem referendarzem litewskim, który będąc wszak zwolennikiem całkowitego ujednolicenia i zniesienia odrębności Litwy, z perspektywy czasu oceniał jednak Zaręczenie wzajemne jako zacieśnienie aktu unii lubelskiej.

Akt ten nie tylko gwarantował coraz bardziej wówczas uszczuplane prawa Wielkiego Księstwa Litewskiego, lecz także - a może przede wszystkim - pełnił istotną rolę na drodze do ujednolicenia i scentralizowania zarządu szczebla centralnego. Nie przesądzano wprawdzie wyraźnie powoływania w przyszłości wyłącznie wspólnych instytucji, lecz stworzono realne ku temu podstawy, zapewniając Litwie we wszystkich jednolitych magistraturach równy z Koroną udział. Dając Litwie poczucie pewnej odrębności, a przede wszystkim równorzędności, Zaręczenie usprawniało zarazem aparat wykonawczy w państwie.

50 VL, t. IX, s. 318 (oblatowane do akt 22 X 1791 r.).

51 H. Kołłątaj, O ustanowieniu i upadku konstytucji polskiej 3 maja 1971, Biblioteka Mrówki, t. 146-151 (b.r.), s. 324. 
W zarządzie lokalnym pozostawiono, jak to było dotychczas, odrębne - choć identyczne co do nazwy i zakresu kompetencji urzędy, zobowiązując się przy tworzeniu nowych urzędów w Koronie takie same tworzyć i na Litwie. Utrzymano w Wielkim Księstwie Litewskim odrębną kasę i jurysdykcję skarbową.

Należy jednoznacznie podkreślić, że Litwa, godząc się na połączenie komisji skarbowych, przywracała wyraźny zapis o federacyjnym charakterze państwa (co pomijała milczeniem Konstytucja) oraz pozycję równą dwu pozostałym prowincjom koronnym łącznie $^{52}$. Biorąc pod uwagę fakt, że w ciągu XVIII wieku Wielkie Księstwo coraz częściej traktowane było wyłącznie jako jedna $z$ trzech prowincji Rzeczypospolitej, można się zgodzić, że Zaręczenie było aktem bardzo korzystnym dla Litwy i w niczym nieuszczuplającym jej rzeczywistych praw i dotychczasowych odrębności.

W tej sytuacji Litwini nie oponowali już przeciwko uchwaleniu prawa o wspólnej Komisji Skarbowej, co też nastąpiło na sesji 29 października. Termin złączenia się obu komisji wyznaczono na dzień 1 luty, wybór zaś komisarzy na marzec 1792 r. ${ }^{53}$

Uchwalenie Zaręczenia wzajemnego obojga narodów było zwieńczeniem procesu kształtowania stosunku Polski do Litwy za panowania ostatniego króla Rzeczypospolitej Stanisława Augusta Poniatowskiego. Nadano mu szczególną formę ustawy zasadniczej, zrównując $z$ aktem unii lubelskiej „i uznając za artykuł paktów

52 Podobnie ocenia to K. Waga, Zaręczenie wzajemne obojga narodów, Przegląd Wileński 1926, r. IX, nr 8, uważając nawet, że właściwym świętem na Litwie historycznej powinien być „nie dzień 3 maja [...], lecz dzień 20 października, w którym kraj nasz chociaż częściowo odzyskał swą samodzielność”. W. Kamieniecki dodaje natomiast, że „była to ze strony Korony znaczna koncesja” uczyniona „w imię wzmocnienia wspólnego organizmu” (Litwa a Konstytucja 3 maja, Warszawa 1917, s. 22). Dodatkowym potwierdzeniem korzystniejszej niż uprzednio sytuacji Wielkiego Księstwa była ustawa oblatowana w aktach 2 listopada 1791 r.: „Rozkład województw, ziem i powiatów $z$ oznaczeniem miast, a w nich miejsc konstytucyjnych dla sejmików w prowincjach koronnych i W. Ks. Litewskiego”, przyznająca Litwie o 14 posłów więcej, podczas gdy Wielkopolska zwiększyła liczbę mandatów zaledwie o 2, a Małopolska o 11. VL, t. IX, s. 326-338; J. Bardach, Konstytucja 3 maja a unia, op.cit., s. 408.

53 Por. W. Smoleński, Ostatni rok Sejmu Wielkiego, Kraków 1896, s. 128. 
konwentów zaprzysięganych przez monarchów przy wstąpieniu na tron" ${ }^{4}$. O znaczeniu, jakie przywiązywano do tego aktu, świadczy fakt, że „w rocznicę koronacji Stanisława Augusta senatorowie i posłowie litewscy $z$ okazji zjednoczenia skarbów i wojska dali w pałacu radziwiłłowskim bal, na którym był obecny król i posłowie zagraniczni” ${ }^{55}$. Wybito też okolicznościowy medal $z$ wyrytym na otoku łacińskim napisem, który brzmiał: „Za Stanisława Augusta zakończona najściślejsza unia, ustanowiona początkowo za Zygmunta Augusta"56.

Podsumowując powyższe rozważania, można stwierdzić, że związek unijny polsko-litewski przetrwał do końca Rzeczypospolitej szlacheckiej57, choć z pewnością w zmienionej, bo zacieśniającej wzajemny związek, formie ${ }^{58}$.

54 J. Bardach, Konstytucja 3 maja a unia, s. 403.

55 W. Smoleński, Sprawa stosunku Litwy, s. 444.

56 N. Kostomarow, Poslednije gody, op.cit., s. 537. Cyt. za J. Bardachem, Konstytucja 3 maja a unia, s. 404 i n., który stwierdza, że w polskich zbiorach nie udało się dotąd odnaleźć tego medalu, może się on znajdować natomiast w Petersburgu, gdzie natrafił nań przed ponad 120 laty Kostomarow.

57 Podobnie O. Halecki, L'évolution historique de l'union polono-lithuanienne, Le Monde Slave 1926, nr 5, s. 292; F.I. Leontowicz, $K$ isstorii administratiwnago stroja litowskago gosudarstwa, Warszawa 1899, s. 38-39; M.A. Jučas, Litowskaja szlachta, s. 409 czy A. Šapoka, Didysis Varsuos reformu lietuviskoji Enciklopedija, t. IV, Kaunas 1937, s. 686. Z nowszych prac opinię tę potwierdziają: J. Malec, Problem stosunku Polski do Litwy, s. 46 i n.; J. Bardach, Konstytucja 3 maja a unia polsko-litewska, s. 404 i n. oraz idem, Konstytucja 3 maja a Zaręczenie Wzajemne Obojga Narodów 1791 roku, Studia Iuridica XXIV 1992, s. 2, s. 24 i n.; T. Wasilewski, Wielkie Księstwo Litewskie $w$ dobie Rzeczypospolitej Obojga Narodów (1569-1795). Federacja dwóch państw i narodów czy państwo jednolite?, Lithuania 1990, nr 1, s. 76; J. Ochmański, Historia Litwy, wyd. III, WarszawaWrocław 1990, s. 178, oraz Z. Szcząska, Ustawa Rządowa z 1791 r., [w:] Konstytucje polskie. Studia monograficzne [...], red. M. Kallas, t. I, Warszawa 1990, s. 58, który podkreśla, że Zaręczenie weszło do rzędu praw konstytucyjnych utrzymując federacyjny charakter państwa polsko-litewskiego.

58 Zwrócił na to uwagę także Paweł Jasienica, pisząc: „Sejm Czteroletni wcale nie pozbawił państwa charakteru federacji, nadał jej tylko formy ściślejsze, bardziej odpowiadające potrzebom czasów nowych. [...] zapędziwszy się trochę zbyt daleko literą tekstu Konstytucji, Zaręczeniem Wza- 
Publicystyka polityczna Sejmu Czteroletniego postulowała wprawdzie możliwie najpełniejsze scentralizowanie i ujednolicenie władzy wykonawczej i administracji w państwie, widząc w tym środek prowadzący do wzmocnienia upadającej Rzeczypospolitej. Jednak nie występowano otwarcie przeciwko unii łączącej od kilku wieków oba narody. Przeciwnie - starano się uzasadniać politykę centralizacyjną jako rozwinięcie zasad unii lubelskiej i zacieśnienie związku unijnego.

Znalazło to odbicie w prawach kardynalnych z $1791 \mathrm{r}$. w pełni akceptujących stosunek unii Polski z Litwą.

Zaręczenie wzajemne było zwieńczeniem procesu przemian zachodzących w stosunku Polski do Litwy w omawianym okresie. Będąc produktem działalności mającej na celu zespolenie władzy wykonawczej w całym państwie, zachowywało jednocześnie odrębność prowincji litewskiej i jej prawa. W Zaręczeniu Litwa wyraziła ostatecznie swą akceptację na centralizację władz, jednak za nie byle jaką cenę, bo za prawo do stanowiska równorzędnego obu pozostałym prowincjom. Miała być ona traktowana nie jako jedna $z$ trzech prowincji, lecz jako równouprawniony drugi człon unii ${ }^{59}$. Nie bez powodu Zaręczenie określano jako odnowienie aktu unii. „Wypada ocenić wysoko rozum polityczny i rozwagę parlamentarzystów polskich i litewskich, którzy - jak podkreślał Juliusz Bardach - umieli powiązać walkę o suwerenność zewnętrzną, o zreformowanie organizacji państwowej z tradycją unii i zachowaniem podmiotowości Wielkiego Księstwa. Raz jeszcze potwierdziły swoją wartość rozwiązania kompromisowe, a także walor parlamentu jako forum ich realizacji” ${ }^{\circ}$, a w innym miejscu dodaje: „Przykład losów

jemnym obwarował, ułatwił dalsze trwanie poczucia odrębności Wielkiego Księstwa”. Podsumowywał to następującą refleksją: „Konstytucja 3 maja wcale nie skasowała odrębności litewskiej. Żaden akt prawny nie może skasować egzystencji stworzonej przez dzieje. Otworzyła jedynie drogę do ściślejszych, doskonalszych form związku”. P. Jasienica, Rzeczpospolita Obojga Narodów. Część trzecia: Dzieje agonii, wyd. 3, Warszawa 1985, s. 295-297, 348.

${ }^{59}$ Por. W. Kamieniecki, Litwa a Konstytucja 3 maja, Warszawa 1917, s. 22.

60 J. Bardach, Konstytucja 3 maja a Zaręczenie Wzajemne, s. 25 i n. 
unii polsko-litewskiej w dobie Sejmu Czteroletniego zdaje się świadczyć, że nie da się urzeczywistnić reform ustrojowych bez społecznego poparcia [...]. I tak jak akceptacja przez senatorów i posłów litewskich Ustawy Rządowej 3 maja stanowiła ustępstwo na rzecz strony polskiej w imię nadrzędnego interesu całej Rzeczypospolitej, tak Zaręczenie Wzajemne Obojga Narodów było ustępstwem na rzecz broniących swojej podmiotowości politycznej Litwinów. Kompromis dokonał się $\mathrm{w}$ ramach istniejącej federacji, zacieśniając ją przez powołanie wspólnych organów opartych na zasadzie równorzędności. Umacniało to więź pomiędzy "narodami politycznymi" Korony i Wielkiego Księstwa Litewskiego, a jednocześnie umożliwiało Litwinom zachowanie tradycji własnej państwowości, istotnego elementu ich współczesnej świadomości narodowej”61.

\section{SUMMARY}

\section{The Mutual Engagement of Both Nations - in the 220 anniversary of enacting}

Present article concerns an unfading controversy about politico-legal meaning of an act of the Mutual Engagement of Both Nations and its interpretation in the context of the fundamental rights of the Polish-Lithuanian Commonwealth, which were enacted in this times, especially the Constitution of the Third May. The contents of the essay makes an order and sums the long-term discussion on the mentioned act, between proponents and opponents of the thesis, which says, that it means the end of the polish-lithuanian political union. The Author, on the base of the analysis of the historical sources, presents his own view, in which sums previous discussion and tries to finally resolve the problem.

Key-words: The Mutual Engagement of Both Nations, polish-lithuanian union, fundamental rights of the Polish-Lithuanian Commonwealth

61 J. Bardach, Konstytucja 3 maja a unia polsko-litewska, s. 410. 